\title{
SISTEM PENDIDIKAN \\ PONDOK PESANTREN DARUL HABIBI NAHDATUL WATHAN (NW) PAOK TAWAH PRAYA LOMBOK TENGAH
}

\author{
Satria Umami \\ STMIK MATARAM \\ satriaumami9@gmail.com
}

\begin{abstract}
Abstrak: Pondok pesantren sebagai penyelenggara pendidikan Islam, secara selektif bertujuan menjadikan sumber daya santri yang handal dan diharapkan dapat menjadi pimpinan umat Islam, oleh karena itu sistem atau komponen sistem pendidikan pondok pesantren harus ditingkatkan. Fokus dari penelitian ini untuk mengkaji sistem pendidikan pondok pesantren Darul Habibi Nahdatul Wathan Paok Tawah Praya Lombok Tengah dalam mencapai tujuan yang di jelaskan dalam rumusan masalah: 1) Bagaimana Sistem Pendidikan Pondok Pesantren Darul Habibi Nahdatul Wathan Paok Tawah Praya Lombok Tengah 2) Bagaimana Hubungan Komponen Sistem Pendidikan Dalam Mencapai Tujuan.
\end{abstract}

\section{Kata Kunci: Sistem Pendidikan Pondok Pesantren, Hubungan Komponen Sistem Dalam Mencapai Tujuan}

\section{Latar Belakang}

Pondok pesantren merupakan penyelenggara pendidikan yang bergerak dalam bidang keagamaan atau juga spiritual, lembaga ini digunakan untuk penyebaran agama dan tempat mempelajari agama secara tradisional. Dikatakan tradisional karena melihat sistem pengajaran yang berlaku pada umumnya adalah sistem sorogan dan bandongan, ( Nouruz Zaman Shidqi, 1986.)

Pondok pesantren sebagai salah satu bentuk penyelenggara pendidikan jalur luar sekolah yang mempunyai potensi, kedudukan dan peranan sangat penting dan strategis untuk mewujudkan sumber daya santri yang berkualitas. Pondok pesantren merupakan sebuah sistem pendidikan klasik dan paling tradisional di Indonesia, namun demikian melalui kebanggaan tradisionalnya, tidak akan dapat dipungkiri bahwa pondok pesantren justru semakin survive, bahkan dianggap sebagai alternatif dalam hegemoni modernisme untuk dapat melahirkan generasi bangsa yang mempunyai sumber daya santri yang tinggi, (Ismail SM,2000)

Pendidikan pesantren memiliki dua sistem pengajaran, yaitu sistem sorogan, yang sering disebut sistem individual, dan sistem bandongan atau wetonan yang sering disebut kolektif. Sistem ini biasanya diberikan dalam pengajian kepada santri-santri yang telah menguasai pembacaan al-Qur'an dan kenyataan merupakan bagian yang paling sulit sebab sistem ini menuntut kesabaran, kerajinan, ketaatan dan disiplin pribadi dari santri. Santri seharusnya sudah paham tingkat sorogan ini sebelum dapat mengikuti pendidikan selanjutnya di pesantren. (Dhofier, Zamakhsyari, 1994)

Metode utama sistem pengajaran di lingkungan pondok pesantren ialah sistem bandongan atau wetonan. Dalam sistem ini, sekelompok santri mendengarkan seorang ustad/guru yang membaca, menerjemahkan, dan menerangkan buku-buku Islam dalam bahasa Arab. Kelompok kelas dari sistem bandongan ini disebut halaqah yang artinya sekelompok siswa yang belajar di bawah bimbingan seorang guru.

Tujuan proses modernisasi pondok pesantren adalah berusaha untuk menyempurnakan sistem pendidikan Islam yang ada di pesantren. Perubahanperubahan yang bisa dilihat di pesantren modern termasuk mulai akrab dengan metodologi ilmiah modern, lebih terbuka atas perkembangan di luar dirinya, diversifikasi program dan kegiatan di pesantren makin terbuka dan luas, dan sudah dapat berfungsi sebagai pusat pengembangan masyarakat.

Pada abad XXI ini, tuntutan yang dihadapi bangsa Indonesia untuk menghasilkan sumber daya manusia (SDM) yang berkualitas semakin mendesak, penguasaan ilmu dan teknologi (IPTEK) serta iman dan taqwa (IMTAQ) sangat dibutuhkan pada era globalisasi ini. Kehidupan pada era globalisasi ini tidak saja membutuhkan insan-insan yang cerdas, berkualitas dan produktif, tetapi juga tenaga yang bermoral dan komitmen terhadap etika, sehingga kelak akan melahirkan manusia seutuhnya.

Berkaitan dengan hal tersebut, pendidikan dianggap solusi yang paling efektif untuk meningkatkan sumber daya santri yang berkualitas, pendidikan mempunyai peranan yang sangat penting untuk menjamin kesejahteraan hidup manusia, Allah SWT memuliakan orang-orang yang mempunyai ilmu pengetahuan, hal ini sebagaimana firman Allah dalam Al-Quran surat Al-Mujadalah ayat 11 yang Artinya: "Allah akan meninggikan derajat orang-orang yang beriman diantara kamu dan orang-orang yang berilmu pengetahuan dengan beberapa derajat.(Depag RI.1982)

Konsep peningkatan sumber daya santri melalui pendidikan ini secara konstitusional telah digariskan oleh Undang-Undang Dasar 1945, Garis-Garis Besar Haluan Negara, dan juga dalam Undang-Undang Republik Indonesia nomor 20 tahun 2003 tentang sistem pendidikan nasional.

Begitu pula dalam GBHN disebutkan bahwa sasaran umum pembangunan jangka panjang II adalah terciptanya kualitas manusia dan kualitas masyarakat Indonesia yang maju dan mandiri dalam suasana tentram dan sejahtera lahir batin, dalam tata kehidupan masyarakat, bangsa dan negara yang berdasarkan pancasila, dalam suasana kehidupan bangsa Indonesia yang berkesinambungan dan selaras dalam hubungan antara sesama manusia, 
manusia dengan masyarakat, manusia dengan alam dan lingkungan, masyarakat dengan Tuhan Yang Maha Esa.

Jika melihat rumusan GBHN tersebut, secara sederhana dapat disimpulkan bahwa tujuan pendidikan nasional adalah mempersiapkan sumber daya santri yang berkualitas. Sedangkan dalam Undang-Undang Republik Indonesia nomor 20 tahun 2003 tentang sistem pendidikan nasional disebutkan bahwa: Pendidikan nasional bertujuan mencerdaskan kehidupan bangsa dan mengembangkan manusia Indonesia seutuhnya, yaitu manusia yang beriman dan bertakwa terhadap Tuhan Yang Maha Esa, berbudi pekerti luhur, memiliki pengetahuan dan ketrampilan, kesehatan jasmani dan rohani, kepribadian yang mantap dan mandiri serta rasa tanggung jawab kemasyarakatan dan kebangsaan.( BP-7. GBHN, Ketetapan MPR No.II/MPR/1993)

Dari tujuan pendidikan nasional sebagaimana tercantum dalam Undang-Undang Republik Indonesia nomor 20 tahun 2003 tentang sistem pendidikan nasional di atas memperjelas bahwa betapa idealnya dan besarnya tanggung jawab pendidikan. Melalui pendidikan diharapkan dapat ditingkatkan kemampuan, mutu kehidupan, dan martabat masyarakat Indonesia. Untuk itulah pendidikan nasional bermaksud menghasilkan manusia terdidik seutuhnya, baik keimanan, budi pekerti, pengetahuan, teknologi, ketrampilan, kepribadian dan rasa tanggung jawab.

Karakteristik Sumber daya santri sebagaimana dipaparkan diatas dapat terwujud melalui pendidikan, baik melalui jalur sekolah maupun luar sekolah, sedangkan salah satu lembaga pendidikan luar sekolah ialah pondok pesantren, senada dengan yang di nyatakan Yacub bahwa pendidikan dapat diperolah lewat jalur formal, informal dan non formal (pendidikan luar sekolah). Sedangkan salah satu pendidikan luar sekolah adalah pondok pesantren.( Yacub, 1995)

Dari uraian tersebut peneliti ingin mencermati sistem pendidikan pondok pesantren di Indonesia khususnya di pulau Lombok. Peneliti ingin mengkaji tentang Sistem Pendidikan Pondok Pesantren Darul Habibi Nahdatul Wathan Paok Tawah Praya Lombok Tengah dalam mencapai tujuan pendidikan, karena melihat betapa tuntutan zaman mengharuskan untuk terus berupaya menjadi manusia yang mempunyai sumber daya yang tinggi, dengan dibekali penguasaan ilmu pengetahuan serta iman dan takwa secara seimbang.

Hal ini sangat menarik, sebab pondok pesantren menyimpan sumber daya manusia (SDM) yang sangat pontensial manakala dikelola dengan manajemen yang strategik, disamping itu pondok pesantren juga mempunyai suatu tradisi hidup mandiri dan penuh tanggung jawab terhadap pelaksanan amanat yang telah diberikan. Mengingat bahwa tantangan yang dihadapi oleh lembaga pendidikan khususnya pondok pesantren semakin hari semakin berat dan semakin komplek.

\section{METODE PENELITIAN}

Penelitian ini untuk mengkaji Sistem Pendidikan Pondok Pesantren Darul Habibi Nahdatul Wathan
Paok Tawah Praya Lombok Tengah dalam pencapaian tujuan. Maka jenis penelitian yang digunakan dalam penelitian ini adalah penelitian lapangan (field research). Field research adalah metode yang secara khusus dan realistis mengenai apa yang terjadi di dalam masyarakat mengenai pristiwa atau fenomena aktual baik di bidang budaya atau sosial dengan pendekatan kualitatif yaitu dengan cara mengumpulkan data yang menggambarkan atau memaparkan apa adanya dari hasil penelitian kemudian disusun dan dituangkan dalam bentuk tulisan, dikatakan kualitatif karena penelitian ini bertujuan untuk mendeskripsikan hasil pengolahan data yang berupa kata-kata dan gambaran umum yang terjadi di lapangan.

Lexy J. Moleong, mendefinisikan pendekatan kualitatif ini sebagai penelitian yang bermaksud untuk memahami fenomena tentang apa yang dialami oleh subjek penelitian misalnya perilaku, persepsi, motivasi, tindakan, dan lain-lain., secara holistik, dan dengan cara deskripsi dalam bentuk kata-kata dan bahasa, pada suatu konteks khusus yang alamiah dan dengan memanfaatkan berbagai metode.( Lexy, J. Moleong, 2005)

Menurut Moh. Nazir penelitian yang menggunakan metode kualitatif bertujuan untuk membuat deskripsi, gambaran atau lukisan secara sistematis, faktual dan akurat mengenai fakta-fakta, sifat-sifat serta hubungan antar fenomena yang diselidiki.( M. Nazir, 1998)

Arikunto dalam bukunya berjudul "Prosedur Penelitian: Suatu Pendekatan Praktek" menjelaskan bahwa: jika penelitian yang dalam pengumpulan data dan penafsiran hasilnya tidak menggunakan angka, maka penelitian tersebut dinamakan penelitian kualitatif. Meskipun demikian, bukan berarti bahwa dalam penelitian kualitatif tidak diperbolehkan menggunakan angka. Dalam hal tertentu bisa menggunakan angka, seperti menggambarkan kondisi suatu keluarga (menyebutkan jumlah anggota keluarga, menyebutkan banyaknya biaya belanja sehari-hari, dan sebagainya), tentu saja bisa. Yang tidak diperbolehkan mempergunakan angka dalam hal ini adalah, jika dalam pengumpulan data dan penafsiran datanya menggunakan rumus-rumus statistik. Sedangkan penelitian yang dalam pengumpulan data dan penafsiran hasilnya menggunakan angka, maka penelitian tersebut dinamakan penelitian kuantitatif.( Suharsini Arikunto, 2002)

Penelitian lapangan digunakan untuk menganalisis berbagai gejala dan fenomena di lingkungan pondok pesantren. Sedangkan pendekatan kualitatif di pergunakan untuk memaknai sistem pendidikan pondok pesantren Darul Habibi Nahdatul Wathan Paok Tawah Praya Lombok Tengah dalam pencapaian tujuan. Berbagai temuan lapangan yang bersifat individual di jadikan bahan utama dalam mengungkapkan permasalahan yang diteliti dengan berpegang pada ketentuan yang normatif.

\section{HASIL PENELITIAN}

Pondok Pesantren Darul Habibi Nahdatul Wathan Paok Tawah Praya Lombok Tengah dalam kurun waktu 21 tahun sejak pendiriannya telah menunjukkan 
perkembangan yang pesat. Bahkan sekarang secara fisik termasuk pondok pesantren tipe $D$, dimana merupakan bentuk pesantren yang sangat diminati masyarakat dewasa ini karena selain menyelenggarakan sistem pondok pesantren sekaligus juga memperlakukan sistem sekolah (madrasah) sehingga di dapatkan keseimbangan antara ilmu pengetahuan umum dengan ilmu pengetahuan Agama.

a. Kondisi Santri dalam kurun waktu 5 tahun terakhir.

Tabel 4.1

Jumlah santri yang diterima tahun 2008-2012 di pondok Pesantren Darul Habibi Nahdatul Wathan Paok Tawah Praya Lombok Tengah.( Hasil dokumentasi hari Rabu tanggal 24 April 2012 )

\begin{tabular}{|c|c|c|c|}
\hline Tahun & $\begin{array}{c}\text { Santri } \\
\text { Putra }\end{array}$ & $\begin{array}{c}\text { Santri } \\
\text { Putri }\end{array}$ & Jumlah \\
\hline $2008-2009$ & 55 & 60 & 115 \\
\hline $2009-2010$ & 64 & 46 & 110 \\
\hline $2010-2011$ & 60 & 70 & 130 \\
\hline $2011-2012$ & 85 & 75 & 160 \\
\hline $2012-2013$ & 80 & 85 & 165 \\
\hline Jumlah & 344 & 336 & \\
\hline
\end{tabular}

b. Fasilitas Pendukung Pendidikan

Tabel 4.2

Fasilitas Pondok Pesantren Darul Habibi Nahdatul Wathan Paok Tawah Praya Lombok Tengah Tahun 2012-2013

\begin{tabular}{|l|l|l|}
\hline No & Nama Komplek & \multicolumn{1}{|c|}{ Fasilitas } \\
\hline 1. & $\begin{array}{l}\text { Gedung sekolah } \\
\text { /madrasah berlantai } \\
\text { tiga }\end{array}$ & $\begin{array}{l}\text { 1 ruang lab. Computer, 1 ruang } \\
\text { perpustakaan, 1 ruang lab. IPA, 9 } \\
\text { ruang kelas, 4 WC/ guru, 4 WC/ } \\
\text { siswa, 2 lapangan upacara, } \\
\text { fasilitas olah raga, 1 ruang guru, 1 } \\
\text { ruang tata usaha 1 ruang parkir. 1 } \\
\text { buah kantin, 1 buah poskestren }\end{array}$ \\
\hline 2. & Asrama Putra & $\begin{array}{l}1 \text { asrama putra, aula, dapur } \\
\text { umum, 5 kamar mandi, 4 buah } \\
\text { WC. 1 buah sumur bor (air } \\
\text { bersih) }\end{array}$ \\
\hline 3. & Asrama putri & $\begin{array}{l}\text { Aula 1 asrama putri, dapur } \\
\text { umum, 5 kamar mandi, dan 4 } \\
\text { buah WC, 1 kantin, 1 tempat olah } \\
\text { raga, 2 buah sumur bor (air } \\
\text { bersih) }\end{array}$ \\
\hline 4. & Masjid & $\begin{array}{l}2 \text { buah WC, 4 buah tempat uduk. } \\
\text { 2 buah sumur bor }\end{array}$ \\
\hline
\end{tabular}

Sistem pendidikan Pondok Pesantren Darul Habibi Nahdatul Wathan Paok Tawah Praya Lombok Tengah merupakan lembaga pendidikan Islam sebagai salah satu tempat keilmuan dan aset keislaman, saling terkait dan saling mempengaruhi dalam pencapaian tujuan pondok pesantren komponen-komponen tersebut ada tuan guru/kyai, asrama/pemondokan, santri, masjid, dan kitab kuning sebagai berikut:Ada dua status santri di pondok Pesantren Darul Habibi Nahdatul Wathan Paok Tawah Praya Lombok Tengah, status ini untuk membedakan seorang santri dalam mempelajari ilmu. Status tersebut yaitu; pertama, santri yang secara khusus mempelajari pengetahuan agama atau memperdalam kitab kuning. Kedua, santri yang belajar di sekolahsekolah formal di lingkungan pondok pesantren. Terbagi dalam beberapa jenjang pendidikan yaitu; santri Madrasah Tsanawiyah (MTs), SMP, Madrasah Aliyah (MA), SMK.

\section{KESIMPULAN DAN SARAN}

Pondok Pasantren Darul Habibi Nahdatul Wathan Paok Tawah Praya Lombok Tengah, serta merujuk kepada rumusan masalah dan tujuan penelitian maka dapat disimpulkan sebagai berikut:

1. Kurikulum pendidikan di pondok pesantren Darul Habibi Nahdatul Wathan Paok Tawah Praya Lombok Tengah memadukan antara ilmu agama dan ilmu umum. Komponen pendidikan terdiri dari Tuan guru/kyai, santri, asrama, masjid, dan kitab kuning.

2. Hubungan antar komponen dalam sistem pendidikan pondok pesantren Darul Habibi Nahdatul Wathan Paok Tawah Praya Lombok saling terkait dan saling mempengaruhi dalam pencapaian tujuan pondok pesantren; mempersiapkan kader ulama yang memiliki kemantapan akidah dan kedalaman spiritual, keagungan akhlak dan keluasan ilmu pengatahuan sehingga berguna bagi agama, masyarakat, bangsa dan Negara.

Adapun saran-saran yang dapat penulis berikan adalah:

1. Dalam belajar kitab kuning (nahwu dan shorof) santri harus lebih berani dalam bertanya kepada Tuan guru/kyai dan ustad.

2. Pengurus pondok pesantren hendaknya lebih meningkatkan kualitas dan sarana prasarana yang ada di asrama supaya santri-santriwati lebih yaman dalam belajar dan beraktifitas.

3. Pemerintah dan masyarakat perlu meningkatkan dukungan dan keterlibatan langsung kepada lembaga pendidikan sebagai perwujudan dari tanggung jawab mengenai pendidikan.

\section{DAFTAR PUSTAKA}

Nouruz Zaman Shidqi, Etika Pembagunan dalam Pemikiran Islam di Indonesia, (Jakarta: CV. Rajawali, 1986), hal. 9

Ismail SM. Signifikansi Pesantren dalam Pengembangan Masyarakat Modern, (Yogyakarta: Pustaka Pelajar, 2000), hal. 171

Dhofier, Zamakhsyari, 1994, Tradisi Pesantren, (Jakarta: LP3ES, 1994), hal. 28

DEPAG RI. 1992. Al-Quran dan Terjemahnya, Jakarta

BP-7. GBHN. 1995. Ketetapan MPR No.II/MPR/1993, Jakarta.

Yacub, Pondok Pesantren dalam Pengembangan Masyarakat Desa, (Bandung: Angkasa, 1995), hal. 146.

Moleong, Lexy, J. 2000. Metode Penelitian Kualitatif, Bandung: PT. Remaja Rosdakarya.

Nazir, M. 1988. Metode Penelitian, Jakarta: Ghalia Indonesia. 
Suharsini Arikunto, Prosedur Penelitian: Suatu Pendekatan Praktek, (Jakarta: Rineka Cipta, 2002), hal. 10 